\title{
A RESTAURAÇÃO CATÓLICO-TOMISTA A PARTIR DO CAMPO POLÍTICO E JURÍDICO DE MINAS GERAIS NA PASSAGEM À MODERNIDADE ${ }^{1}$
}

LA RESTAURACIÓN CATÓLICO-TOMISTA A PARTIR DEL CAMPO POLÍTICO Y JURÍDICO DE MINAS GERAIS EN EL PASAJE A LA MODERNIDAD

\section{THE CATHOLIC-THOMIST RESTORATION BASED ON THE POLITICAL AND}

LEGAL FIELD IN MINAS GERAIS IN THE PASSAGE TO MODERNITY

\section{LA RESTAURATION CATHOLICO-THOMISTE A PARTIR DU CHAMP POLITIQUE ET JURIDIQUE DE MINAS GERAIS DANS LE PASSAGE VERS LA MODERNITE}

DOI: 10.5533/1984-2503-20102507

Jefferson de Almeida Pinto

\section{RESUMO}

Partindo do processo de restauração católico-tomista empreendido pela Igreja romana nas primeiras décadas do século XX, este artigo procura discutir como este processo ocorreu a partir de Minas Gerais tendo por base seu campo político e jurídico. Utilizamos como fontes principais reportagens, entrevistas e notas publicadas na imprensa mineira onde percebe-se, num primeiro momento, uma filiação ideológica às ideias modernas, como o liberalismo e o positivismo, quando não envolvidas em um universo maçom. Já num segundo momento, identifica-se um deslize dos campos em questão para o campo católico em processo de reestruturação quando se passa a renegar ou ainda omitir as filiações ditas modernas e aderir à filosofia tomista.

Palavras-chave: restauração católica, ideias políticas e jurídicas, intelectuais.

\section{RESUMEN}

Partiendo del proceso de restauración católico-tomista emprendido por la Iglesia romana en las primeras décadas del siglo XX, este artículo busca discutir como este proceso ocurrió a partir de Minas Gerais teniendo como base su campo político y jurídico. Utilizamos como principales fuentes reportajes, entrevistas y notas publicadas en la

\footnotetext{
${ }^{1}$ Este artigo foi elaborado a partir de nossa pesquisa de doutorado, atualmente em desenvolvimento junto ao Programa de Pós-graduação em História da Universidade Federal Fluminense (UFF), sob orientação da Professora Doutora Gizlene Neder, na qual estudamos a circulação e os usos das ideias jurídico-penais e suas tensões com a cultura religiosa em Minas Gerais.
} 
prensa "mineira" donde se percibe, en un primer momento, una filiación ideológica a las ideas modernas, como el liberalismo y el positivismo, y algunas veces envueltas en un universo masón. En un segundo momento, se identifica un desliz de los campos en cuestión hacia el campo católico en proceso de reestructuración cuando se empieza a renegar o incluso omitir las filiaciones dichas modernas y adherirse a la filosofía tomista. Palabras-clave: restauración católica; ideas políticas y jurídicas, intelectuales.

\section{ABSTRACT}

Considering the Catholic-Thomist restoration process carried on by the Roman Church in the first decades of the 20th century, this paper discusses how this process took place in Minas Gerais based on this State's political and legal field. Our main sources are reportages, interviews and notes published in the local press. They show, in a first moment, the ideological filiation to modern ideas, as liberalism and positivism, or even ideas involved in a Freemason universe. In a second moment, we identify that the mentioned transition to the catholic field, which was restructuring itself. People then began to deny or omit the the so called modern filiations to adhere to Thomist philosophy.

Key-words: Catholic restoration; legal and political ideas, intellectuals.

\section{RÉSUMÉ}

L'église romaine a entrepris un processus de restauration catholico-thomiste dans les premières décennies du $X^{e}$ siècle. Cet article discute comment ce processus a eu lieu à Minas Gerais en se basant sur le champ politique et juridique de cet État. Nos sources principales sont des reportages, des entrevues et des notes publiées dans la presse locale qui montrent, dans un premier moment, une filiation idéologique aux idées modernes, comme le libéralisme et le positivisme, ou même à des idées provenant d'un univers maçon. Dans un second moment, nous identifions un glissement des champs en question vers la sphère catholique en cours de restructuration qui commence par un reniement ou une omission des filiations dites modernes avant de se transformer en adhésion à la philosophie thomiste.

Mots-clefs: restauration catholique; idées politiques et juridiques; intelectuels.

Este artigo tem por objetivo discutir o processo de restauração católica no Brasil a partir de suas relações com o campo político e jurídico de Minas Gerais. Nele, 
procuramos destacar um conjunto de ideias que, no século XIX, foi alvo de ataques da Igreja romana e que, nas primeiras décadas do século $\mathrm{XX}$, foi gradativamente contornado, em função de sua aproximação estratégica com setores dos quais ela havia sido afastada quando do advento republicano no Brasil. Insere-se, portanto, num intervalo marcado por uma forte polarização ideológica que data de fins do sistema imperial até as primeiras décadas do sistema republicano.

Assim sendo, na segunda metade do século XIX, podemos dizer que muitos dos agentes dos campos em questão estavam debruçados sobre uma literatura embasada nas principais ideias que circulavam pelas instituições científicas e culturais do país. De um lado, o liberalismo e o positivismo podem ser considerados ideias que povoavam os círculos acadêmicos e políticos, sendo consumidas ou reproduzidas a partir de um vasto mercado de letras que vai da formação de bibliotecas, publicação de jornais até outros periódicos que circulavam não somente nas principais cidades, mas também em pontos bem diversos do país, como vamos demonstrar. Liberais e positivistas serão os responsáveis, em grande parte, pelas profundas críticas direcionadas ao governo monárquico, sobretudo após a década de 1870, quando as posturas republicanas e abolicionistas de muitos daqueles que estavam à frente dos destinos políticos do Império se tornarão ainda mais acentuadas.

Uma das razões destas críticas estaria na presença da Igreja Católica, por meio de suas ordens religiosas, como seria o caso da Congregação da Missão² ${ }^{2}$, na vida política do Estado. ${ }^{3}$ Embora a Constituição Imperial de 1824 impusesse limitações à ação da Igreja

\footnotetext{
${ }^{2}$ A Congregação da Missão ou Congregação dos Lazaristas ou ainda Congregação dos Vicentinos foi fundada por São Vicente de Paulo em 1626 para fomentar as missões junto a uma população pobre e em estado de abandono espiritual e material por parte da Igreja e de suas Ordens Mendicantes. Ao fundar a Congregação da Missão, São Vicente desejava também que as diretrizes traçadas para a Igreja a partir do Concílio de Trento (1545-1563) fossem colocadas em prática. Vicente de Paulo entendia que competia aos clérigos pregar não somente o evangelho, mas de alguma forma intervir na realidade social. A Confraria das Damas da Caridade, fundada em 1617 e a Congregação das Irmãs da Caridade, ou Irmãs Vicentinas, fundada por uma Dama da Caridade chamada Luíza de Marilac em 1633 com o auxílio de Vicente de Paulo constituem a família vicentina. No século XIX, o hoje beato Antônio Frederico Ozanan fundaria na França a Sociedade São Vicente de Paulo voltada para atuar junto aos pobres daquele país vitimados pela exploração burguesa quando da formação de sua sociedade industrial e hoje presente em vários países do mundo católico. Ver: Ubillús, P. José Antônio (2003). Passo a passo com São Vicente, Oficina ㄲo 3, Dezembro/2003, p. 4. (mimeografado). Disponível também em http://www.aicinternational.org/pdf/pas34port.pdf acesso em 30 de julho de 2009. Entendemos que, em função da expulsão dos jesuítas, assim como de seu enfraquecimento quando do retorno de suas atividades, coube aos Lazaristas a função de encampar a Reforma Ultramontana no Brasil, com destaque para a atuação do bispado marianente na figura de Dom Antonio Ferreira Viçoso, um dos primeiros Lazaristas a se estabelecer no Brasil com a autorização de Dom João VI no Santuário do Caraça em Minas Gerais. Ver: Miceli, Sergio (1988). A elite eclesiástica brasileira, Rio de Janeiro: Bertrand Brasil, p. 82.

${ }^{3}$ Ver: Nabuco, Joaquim (1873). O partido ultramontano: suas invasões, seus órgãos e seu futuro. Artigos publicados, Rio de Janeiro: Typografia da Reforma e Nabuco, Joaquim (1873). A invasão ultramontana. Discurso pronunciado no Grande Oriente do Brasil, dia 20 de maio de 1873, Rio de Janeiro: Typographia Franco-Americana.
} 
por meio do sistema de padroado e do beneplácito régio ${ }^{4}$, este mesmo sistema trazia-lhe ganhos materiais consideráveis, assim como sua condição de religião oficial do Estado Ihe reservava vantagens políticas. Neste caso, setores importantes para que o país pudesse passar por transformações culturais substanciais, como seria o caso da educação básica, preservavam-se nas mãos do clero regular, como as Irmãs Vicentinas. ${ }^{5}$ Essa presença da Igreja na vida da sociedade brasileira tornou-se cada vez mais incisiva quando, no século XIX, a mesma intensificou seu processo de Reforma Ultramontana. Neste momento, seria necessário reorganizar a vida clerical, assim como reaproximar-se dos fiéis que, no Brasil, de um modo geral, tinham limitadas participações na vida religiosa. Complementando esse processo, em 1879, por meio da Encíclica Aeterni Patris, a Igreja romana também assumiria o tomismo enquanto filosofia oficial. ${ }^{6}$

Essa postura assumida pela Igreja era também estratégica quanto às modernidades que influenciavam cada vez mais tanto os cidadãos quanto a política. Liberais e positivistas, ao defenderem a separação entre Estado e Igreja, buscavam programar reformas que, entendia-se, teriam reflexos diretos na vida das pessoas. $O$ sistema republicano, ao ser implantado em 1889, concretizou muitas dessas aspirações. O conceito do que realmente viria a ser uma república passou a ser enfatizado por aqueles que estavam à frente do novo sistema. Medidas simples, como a substituição do "Deus guarde vossa senhoria" pelo "Saúde e Fraternidade", acompanhadas por uma iconografia que fazia referências à primeira República francesa (1792-1804) nos documentos oficiais, refletiam um pouco do que estaria por vir no que se refere ao enfraquecimento da Igreja no Brasil. Se, no Império, vigários colados, padres, bispos ou outros membros do corpo eclesiástico eram considerados funcionários do Estado e para isso recebiam proventos do erário público, a República impôs a necessidade de que os mesmos buscassem seu sustento e o de suas capelas e paróquias. A educação, um setor importantíssimo para as pretensões ultramontanas da lgreja, acabou sendo um dos principais alvos dos republicanos brasileiros. O controle sobre as escolas, os professores

\footnotetext{
${ }^{4}$ Em linhas gerais, o padroado seria um direito que tinha o Estado Imperial de intervir na nomeação de bispos e na abertura de novos templos. Não seria propriamente uma novidade, pois os reis de França, Espanha e Portugal já faziam jus a esse direito a fim de organizar a religião católica em suas possessões ultramarinas, já desde o século XVI; já o beneplácito (previsto na Constituição em seu artigo 102, §14) preconizava necessidade de assentimento estatal para que pudessem vigorar os atos das autoridades eclesiásticas no Império. As relações da monarquia portuguesa, assim como da brasileira, com o padroado podem se melhor compreendidas a partir de Vieira, David Gueiros (s/d). O protestantismo, a maçonaria e a questão religiosa no Brasil. 2 ed, Brasília: Editora da UnB, p. 28-29.

${ }^{5}$ Azzi, Riolando (1992). A Igreja e o menor na historia social brasileira, São Paulo: Cehila/Edições Paulinas, p.64-69.

${ }^{6}$ Vieira, D. G. (s/d). Op. cit, p. 32-38.
} 
e o próprio ensino religioso foram substituídos por uma política de ensino, laico, tal como

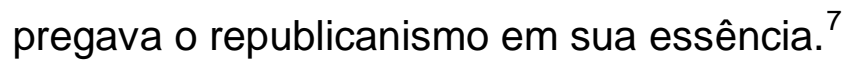

Essa onda de transformações drásticas na vida da lgreja não passou sem que os "culpados" viessem a ser apontados. Não somente os liberais e positivistas seriam responsabilizados pelos prejuízos que estariam sendo impostos ao povo brasileiro, na concepção da Igreja evidentemente, mas também aqueles que, entendia-se, seriam os responsáveis por sua propagação, isto é, maçons e protestantes. Como é sabido, os primeiros estiveram no centro de uma querela entre o Estado brasileiro e os bispos ultramontanos de Olinda e Belém - Dom Vital Maria e Dom Macedo Costa, respectivamente - entre 1872 e $1875^{8}$ e à sua sociabilidade é possível discutir a formação de uma ilustração brasileira no século XIX. ${ }^{9}$ Esse conflito, no entender de David Gueiros, reflete também um receio da lgreja de que o protestantismo viesse a assentar-se cada vez mais no Brasil, haja vista a sua grande circulação em locais como a Amazônia, cuja região fora aberta à navegação estrangeira na segunda metade do século XIX e, constase, impressos protestantes circulavam entre os moradores da região, assim como entre os de outros cantos do Brasil, devido a importação de mão de obra de Estados

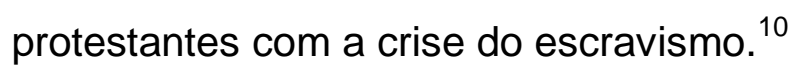

O problema em relação ao protestantismo era que o mesmo trazia consigo mais liberalismo. Seria ainda uma ameaça às pretensões da Igreja no tocante à formação das igrejas nacionais, à defesa do casamento civil e do ensino leigo, aos quais o Syllabus (1869) de Pio IX (1846-1878) era definitivamente oponente. Aliado a isso, entende-se que havia, por parte dos setores liberais do Brasil, um relativo fascínio pelo mundo anglosaxão. ${ }^{11}$ Na visão de Antônio Gouvêa Mendonça essa admiração não é necessariamente resultado das relações de dependência política datadas desde os tempos coloniais, mas sim de um interesse, pelo menos teórico, nos modelos progressistas originários da Inglaterra ou da América do Norte. Neste quadro, a explosão da "questão dos bispos" fez com que as mentes mais ativas daquele tempo acabassem tomando partido "se não contra a lgreja como expressão religiosa, pelo menos como instituição portadora do

\footnotetext{
${ }^{7}$ Ver: Azzi, Riolando (2008). História da Igreja no Brasil. Terceira Época - 1930-1964, Petrópolis: Vozes.

${ }^{8}$ Além dos referidos bispos também eram considerados ultramontanos $\mathrm{D}$. Romualdo Seixas, arcebispo da Bahia, D. Antônio Ferreira Viçoso, bispo de Mariana, D. Antônio Joaquim de Melo bispo de São Paulo, entre outros. A este respeito ver Miceli, S. (1988). Op. cit.

${ }^{9}$ Ver: Barata, Alexandre Mansur (1999). Luzes e sombras: a ação da maçonaria brasileira, Campinas: Editora da Unicamp.

${ }_{10}$ Ver: Vieira, D. G. (s/d). Op. cit, p. 67.

${ }^{11}$ Mendonça, Antônio Gouvêa; Velasques Filho, Prócoro (2002). Introdução ao protestantismo no Brasil. 2 ed, São Paulo: Edições Loyola/Programa Ecumênico de Pós-graduação em Ciências da Religião, p. 69. O fascínio em questão é abordado também em Freyre, Gilberto (1948). Ingleses no Brasil, Rio de Janeiro: Livraria José Olympio Editora.
} 
espírito antiliberal e antiprogressista" tornando, esse momento, "um conflito de mentalidades diferentes, de projetos de orientação política."12

Percebe-se, portanto, que, após a década de 1870, a década da "questão dos bispos", houve uma expansão do protestantismo por meio da educação. Atrelado à noção de liberalismo, assim como aos modelos anglo-saxões de progresso, expressos no comércio ou na agricultura, este foi bem recebido pela classe dominante brasileira, interessada na ruptura com os modelos educacionais ainda fundados no sistema escolástico da Companhia de Jesus. Diz Antônio Gouvêa Mendonça que essas classes não estavam interessadas na religião protestante, mas sim na educação - de corte liberal, é preciso que se diga - que missionários protestantes podiam oferecer proporcionando um grande sucesso à iniciativa da educação protestante naquelas últimas décadas do oitocentos no Brasil. ${ }^{13}$

Não obstante toda essa situação desfavorável, o século XIX também seria marcado pela presença do galicanismo, do regalismo e do jansenismo. Em linhas gerais, os dois primeiros reforçavam ainda mais a submissão da Igreja aos interesses do Estado. Em outras palavras, haveria um reforço ainda maior do padroado, o que limitava sobremodo a livre ação clerical no Império. Já o jansenismo, além de aprofundar este debate, teria uma série de princípios revivificadores da vivência religiosa católica que o aproximava em muito da postura protestante e o faria ser bem recebido por um conjunto de homens que, embora católicos, viam-se na necessidade de aderir à ilustração. ${ }^{14}$

Mas o que tudo isso teria haver com o campo jurídico? O fato é que este ambiente conflitante também se refletirá no que toca às ideias e ideologias que estarão influenciando aqueles que atuavam direta ou indiretamente, com o saber jurídico. Como têm demonstrado os estudos relacionados à história das ideias políticas e jurídicas, é

\footnotetext{
${ }^{12}$ Mendonça, Antonio Gouvêa; Velasques Filho, Prócoro (2002). Op. cit, p. 70.

13 Ibidem, 73-74. Na busca pelo entendimento desta inserção protestante no Brasil do século XIX nos deparamos com a publicação The evangelical invasion of Brasil or, A half century of evangelical missions in the land of the southern cross publicada originalmente em 1910, com 176 páginas, pela Presbyterian committee of publication e reeditada em 2008, a qual referendamos: Gammon, Samuel Rhea (2008). The evangelical invasion of Brasil, Bibliolife. Gostaríamos de destacar também a imigração para o Brasil de muitos missionários da Igreja Metodista Episcopal do Sul dos Estados Unidos durante e após a Guerra Civil Norte-americana (1861-1865) que, entre outras regiões, acabaram fixando-se na cidade mineira de Juiz de Fora já em 1884 e na qual fundariam em 1889 o Instituto Granbery da Igreja Metodista, o qual contaria, já em 1890, com seu primeiro curso superior de Teologia. Era pretensão da Igreja Metodista que o Granbery viesse a se tornar a primeira Universidade Protestante do Brasil. Cursos de Odontologia, Farmácia e Direito chegaram a funcionar no instituto, mas, em virtude de vários problemas, entre eles as pressões da Igreja Católica, esse projeto acabou não indo em frente. Ver: Maia, Almir de Souza (2000). "O descobrimento tardio: as raízes, o nascimento e os atuais desafios da universidade brasileira". In Impulso: Revista de Ciências Sociais e Humanas da Universidade Metodista de Piracicaba. Piracicaba. v. 12, nำ27, p. 27.

${ }^{14}$ Vieira, D. G. (s/d). Op. cit, p. 28-32. Ainda sobre as relações entre a política e a Igreja em Portugal e no Brasil ver Beal, Tarcísio (1977). "As raízes do regalismo brasileiro". In Revista de Cultura Vozes. Petrópolis: Vozes, vol. LXXI, no 3, p. 239-240 e Santos, Cândido (2007). O jansenismo em Portugal, Porto: Faculdade de Letras da Universidade do Porto.
} 
possível identificar uma grande tensão entre um conjunto de intelectuais, oriundos do campo jurídico e atuando no interior do campo de poder, tidos por ilustrados, ou ainda, católicos ilustrados, e os ultramontanos, tendo em vista as disputas, por exemplo, pelo controle da família, já desde o Segundo Reinado. ${ }^{15}$

Assim sendo, ao nos debruçarmos sobre nosso objeto é possível observar como o discurso daqueles que estarão à frente das instituições voltadas para a produção e a reprodução do saber jurídico em Minas Gerais pautar-se-ão nas concepções liberais e positivistas - além de seus vínculos com a maçonaria - para pensar o direito e seu papel na construção do Estado republicano. Os periódicos jurídicos publicados neste intervalo nos permitem identificar como estes saberes acabam por pontuar o discurso dos intelectuais do campo jurídico. Alguns dos tabloides jurídicos das últimas décadas do século XIX serão pontuais em relação à empolgação que as ideias republicanas exerciam sobre a mocidade acadêmica, embora tenhamos que levar em consideração todo clamor que as ideias da modernidade normalmente exerceriam sobre o público acadêmico. Verifica-se também um quadro em que o casamento civil e as concepções científicas voltadas para a área penal também estivam sendo discutidas e defendidas em futuros projetos do Estado. ${ }^{16}$

Outra diretriz, como dissemos, que se relacionaria à crença nas ideias modernas também seria perceptível por meio destas fontes: a educação. Alvo de disputas no período republicano, acreditava-se que a escola deveria ser voltada para a qualificação e formação de um perfil de família positivista, diferente da tridentina, vigorante até então. A formação dos institutos educacionais em Minas Gerais seria um dos horizontes a ser seguido por seus governantes, que deveriam ministrar desde o ensino superior à instrução de outros setores da população, formando-se assim os alicerces do ensino prático e profissional, em instituições que seriam dotadas de laboratórios, gabinetes, museus, coleções, publicação de revistas científicas e literárias e conferências em suas dependências, dizia Afonso Pena ${ }^{17}$, à época da instalação da Faculdade Livre de Direito de Minas Gerais em 1892. ${ }^{18}$

\footnotetext{
${ }^{15}$ Cerqueira Filho, Gisálio (2007). "Augusto Teixeira de Freitas por Joaquim Nabuco: ultramontanismo versus catolicismo ilustrado". In Neder, Gizlene \& Cerqueira Filho (2007), Gisálio. Ideias jurídicas e autoridade na família, Rio de Janeiro: Revan, p. 83-94.

${ }^{16}$ BN. Setor de obras raras. Imprensa Acadêmica, 20 de maio de 1893, p. 1, col. 1,2 e 3 e Academia. Julho, 1897, p. 1 , col. 2 e 3 e p. 2, col. 1.

${ }^{17}$ Afonso Pena, enquanto estudante na Academia de Direito de São Paulo, pertenceu a uma associação estudantil (dita) secreta, nos moldes da Maçonaria, denominada Burschenschaf ou simplesmente Bucha, seu nome simplificado e abrasileirado. Almeida Filho, José Carlos de (2005). O ensino jurídico, a elite dos bacharéis e a maçonaria no século XIX, Rio de Janeiro. Dissertação (Mestrado em Direito, Estado e Cidadania) - Universidade Gama Filho, Rio de Janeiro, p. 9, 50 e 96. Sua fala e seu posicionamento político em relação à educação apreendidos em seu discurso na instalação da Faculdade Livre de Direito de Minas
} 
Mais uma vez, o liberalismo e a possibilidade de se dar mais autonomia às antigas províncias foram os elementos de destaque no que se refere à necessidade de difundir o ensino pelo estado não mais dependente do governo central.

A instrução pública mereceu cuidados dos poderes públicos mineiros; e desde o governo provisório uma série de medidas se iniciaram, improfícuas algumas, inçadas outras de lacunas oriundas da precipitação do momento, mas todas cheias de vontade para difundirem o ensino nessa massa espessa de população mineira, privada do convívio da civilização, privada do próprio conhecimento dos sucessos importantes de sua terra e, portanto, do interesse pela sua grandeza. ${ }^{19}$

Em outro ponto desta citação, o inglês Stuart Mill seria lembrado, pois, segundo ele, mesmo em um sistema de governo mais aperfeiçoado, se o povo não tivesse a devida elevação moral e intelectual, este tenderia a ser burlado. Mirando-se nesta concepção, diz-se que aos legisladores mineiros coube o aperfeiçoamento dos sistemas educacionais, dotando o homem de meios de efetiva emancipação. Neste caso, em Minas Gerais haviam sido criadas instituições de ensino, como a Faculdade de Direito, a Academia de Comércio, a Escola de Farmácia, o Ginásio Mineiro (internato e externato), 10 escolas normais oficiais e duas livres, os institutos agronômicos e zootécnicos, os diversos estabelecimentos de instrução secundária criados por câmaras municipais e cerca de duas mil cadeiras de instrução primária, ultrapassando estas medidas a qualquer outro estado da federação. ${ }^{20}$ Diferentemente do período imperial, quando, diz-se, as iniciativas particulares estariam sempre voltadas para o lucro, as iniciativas que então se davam naquele findar de século XIX seriam a prova de que os princípios do liberalismo inglês na educação estariam sendo aplicados e seriam realmente eficazes. ${ }^{21}$

Em linhas gerais, a necessidade de que o direito se desvinculasse das influências da Igreja externava-se nos escritos jurídicos do final do século XIX. Além de autores que se voltarão para a discussão da filosofia do direito, historiadores, filósofos (entre empiristas, evolucionistas, positivistas e iluministas), médicos, biólogos, matemáticos,

Gerais, assim como outras passagens da Revista da Faculdade Livre de Direito de Minas Gerais, nos chamou a atenção em função dos caracteres da sociabilidade maçônica descrita por Alexandre Mansur Barata. Ver: Barata, A. M. (1999). Op. cit., p.138-143.

${ }_{10}^{18}$ BN. Setor de periódicos. Resenha Jurídica. Ouro Preto, janeiro-dezembro, 1893, p. 5-9.

${ }^{19}$ BSTF. Revista da Faculdade Livre de Direito de Minas Gerais. Rio de Janeiro: Typ. Leuzinger, 1895, p. 143. Grifo nosso.

${ }^{20}$ BSTF. Revista da Faculdade Livre de Direito de Minas Gerais. Rio de Janeiro: Typ. Leuzinger, 1895, p. 145.

${ }^{21}$ BSTF. Revista da Faculdade Livre de Direito de Minas Gerais. Rio de Janeiro: Typ. Leuzinger, 1895, p. 144. 
químicos serão também lembrados. Portanto, áreas do saber recorrentes entre os intelectuais do século XIX, se formos tomar por referência a posse de livros e textos e sua consequente circulação nas instituições de ensino jurídico e em bibliotecas públicas daquele tempo.

Se tomarmos ainda os países em que esses intelectuais nasceram ou que tiveram sua atuação intelectual, veremos como a França era um centro de onde provinham muitas das ideias que iriam "alimentar" esses intelectuais. Neste caso, os clássicos do pensamento iluminista - o barão de Montesquieu, Jean-Jacques Rousseau, D'Alembert, Diderot - ou ainda os revolucionários da Convenção Montanhesa - Maximillien Robespierre e Georges Danton - seriam lembrados. Da Alemanha vinham referências a Karl von Savigny, Christian Matthias Teodor Mommsen, Rudolf von Ihering, embora muitos de seus escritos fossem lidos em língua francesa. Entre os ingleses coube a lembrança a Herbert Spencer, talvez o inglês mais destacado daquele tempo, e a Thomas Huxley cuja alcunha seria "o bulldog de Darwin". ${ }^{22}$

\section{Gráfico 1}

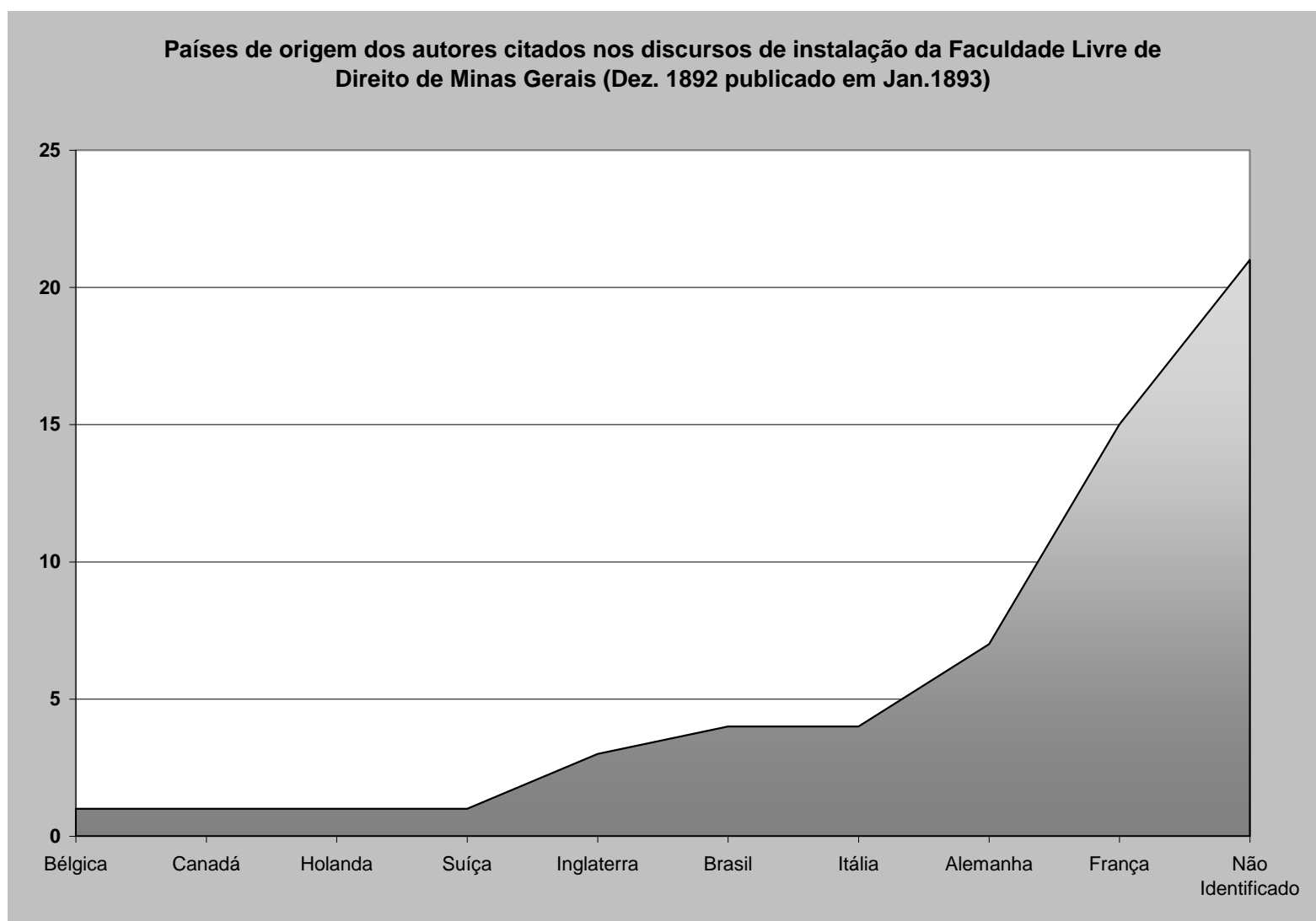

Gráfico 2

${ }^{22}$ BN. Setor de periódicos. Resenha Jurídica. Ouro Preto, janeiro-dezembro, 1893, p. 5-11 e p. 24-32 
Áreas de atuação dos autores citados nos discursos de instalação da Faculdade Livre de Direito de Minas Gerais (Dez. 1892 publicado em Jan.1893)

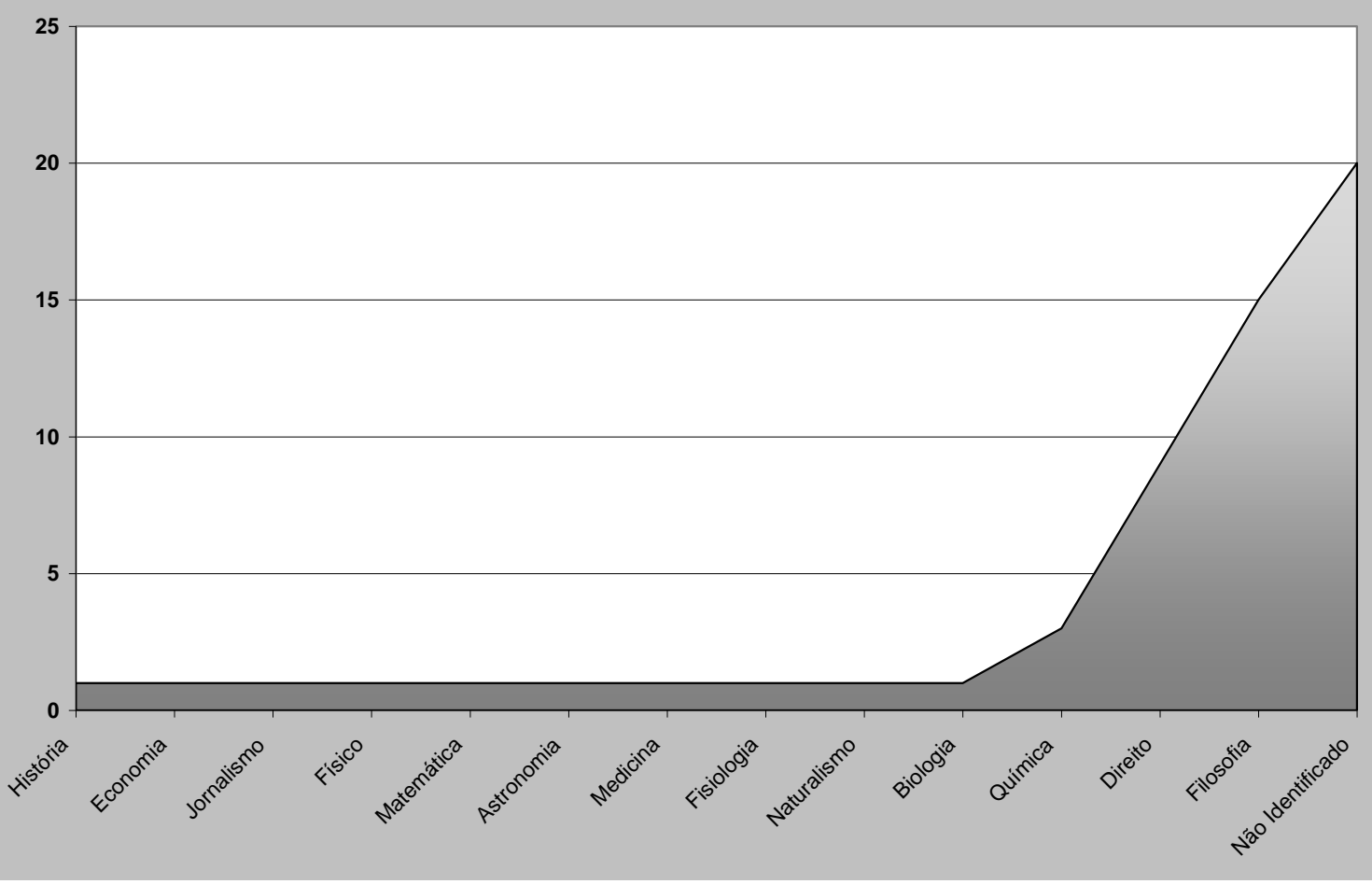

Fonte: BN. Setor de Periódicos. Revista Resenha Jurídica.

\section{Gráfico 3}

Países de origem dos autores citados - artigos selecionados/Revista da Faculdade Livre de Direito de Minas Gerais (1894-1929)

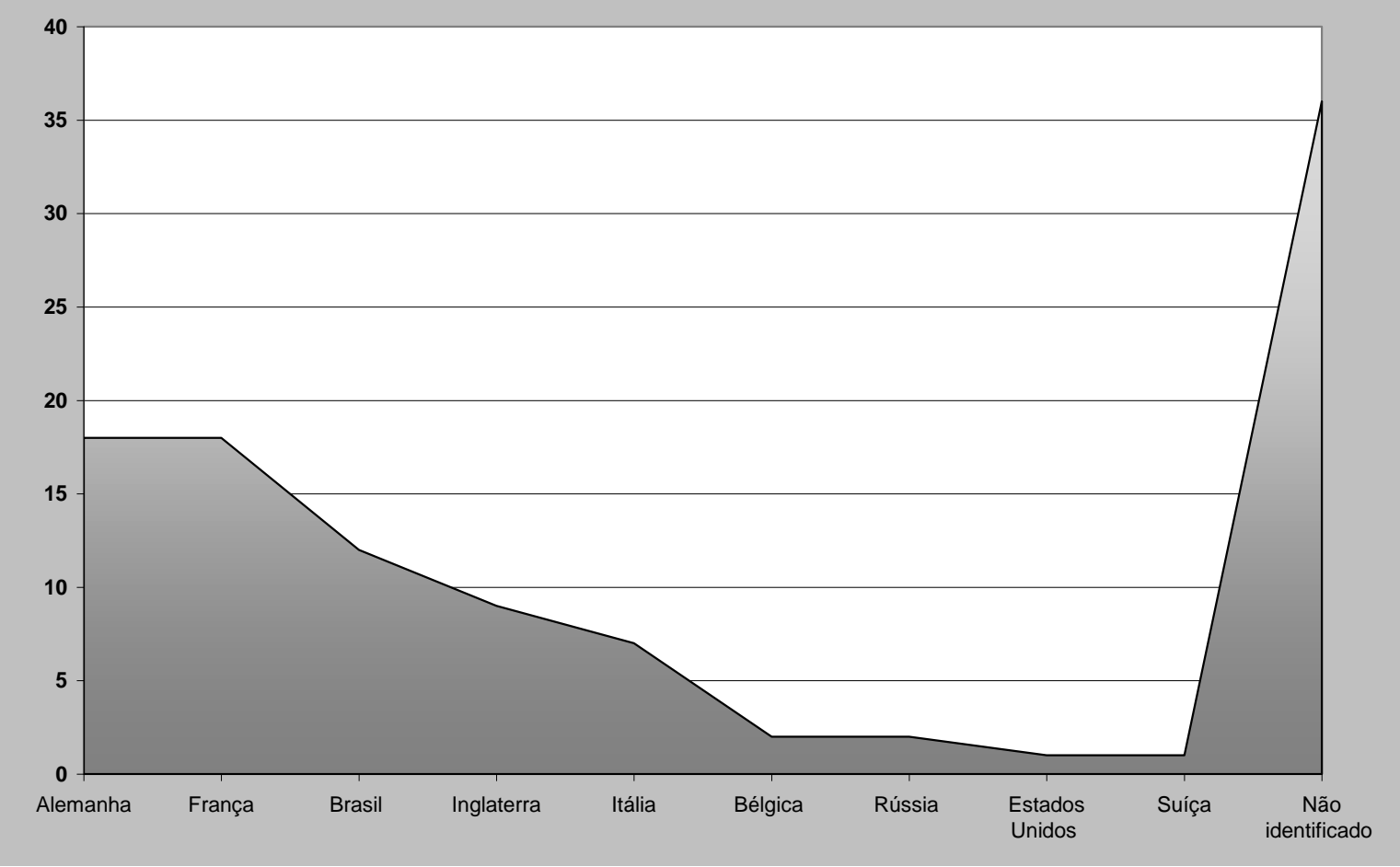

Gráfico 4 


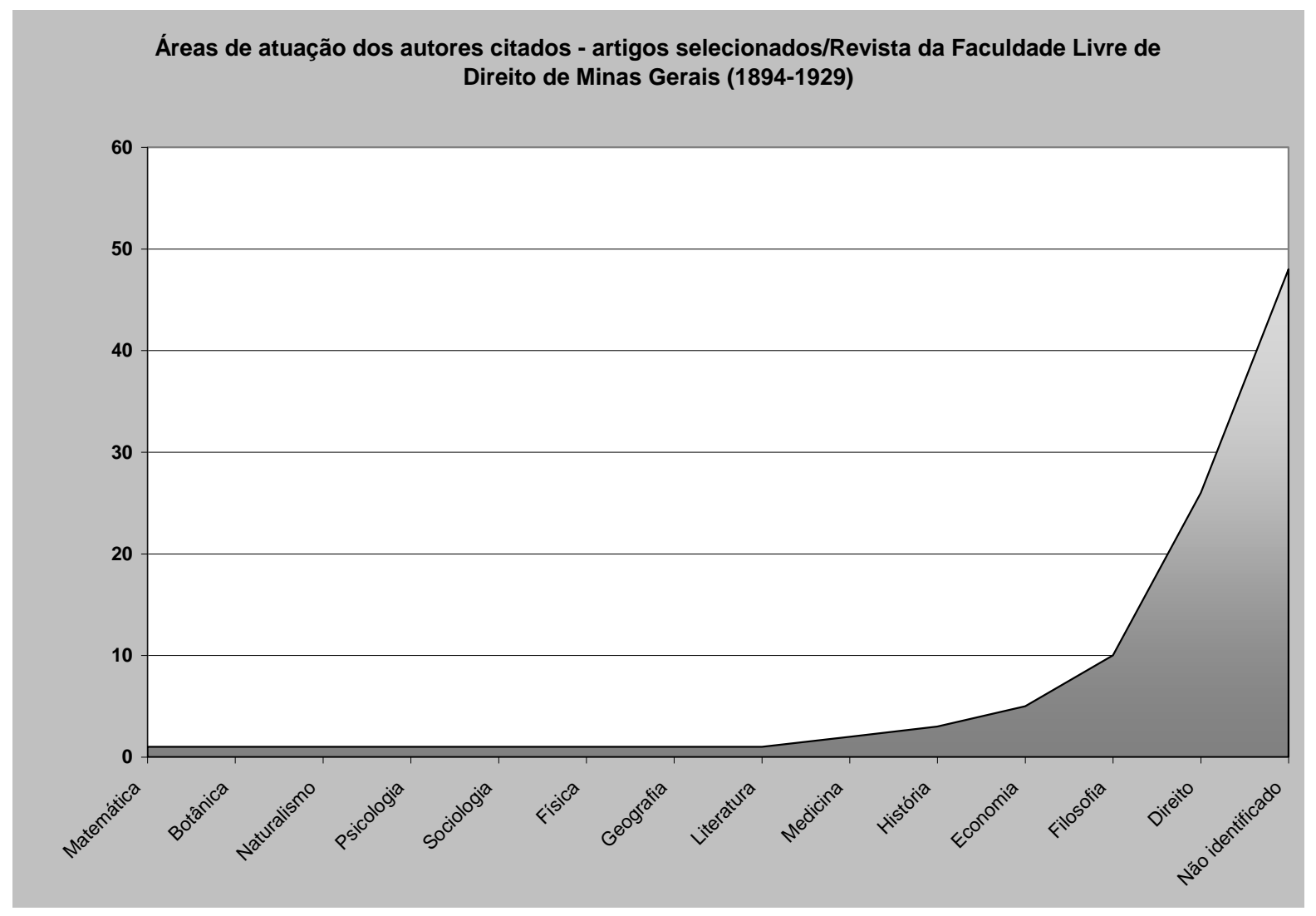

Fonte: BN. Setor de Periódicos. Revista da Faculdade Livre de Direito de Minas Gerais.

Como é possível constatar a partir dos gráficos anteriores, uma literatura, assim como autores, provenientes da Itália e da França seria recorrente entre os intelectuais do campo jurídico neste período. Em relação à Itália, pode-se destacar temas relacionados ao direito penal, tendo em vista a grande produção que esta área terá naquele país se levarmos em consideração, entre outros, que por lá se deram as primeiras reformas nesta área influenciadas pela ilustração, ainda no século XVIII, assim como as referências à criminologia lombrosiana no século XIX. Em relação à França, cabe destaque à área civil. Não custa mencionar o referencial que este país seria para esta área do saber jurídico, pois o primeiro código civil moderno, ao gosto da burguesia que esteve à frente do "18 Brumário" no ano VII da República francesa, fora o Código Napoleônico.

Essas constatações conferem com os dados bibliográficos levantados por Gizlene Neder e Gisálio Cerqueira Filho quanto à circulação de livros, textos, ideias e pessoas pelo Atlântico, num processo que levaria a modernização das instituições jurídicas portuguesas e brasileiras nos quadros do lluminismo de fins do século XVIII. No entender de ambos, o interesse pela produção textual oriunda da França seria um referencial importante de um país que há pouco mais de um século havia destruído as instituições do 
Antigo Regime com a eclosão da Revolução de 1789 e com isso impulsionado a produção textual com o intuito de afirmar as ideias de ilustração. ${ }^{23}$

Este espírito, este vínculo com a modernidade, aparece também nas memórias da Faculdade Livre de Direito de Minas Gerais ao se remeter às transformações por que passaram as ideias em Portugal à época em que Pombal reformou o ensino jurídico e, por conseguinte, abriu o reino - alguns anos mais tarde, é claro - à revolução científica. Essa mudança implementada pelo pombalismo português possibilitou, assim, que os alicerces da independência do Brasil fossem construídos, diz a Revista da Faculdade Livre de Direito de Minas Gerais. ${ }^{24}$ A época pombalina parece ter sido, assim, um momento de grande importância para os homens das minas, pois, em virtude de ser a região de maior opulência no Brasil colonial, possibilitou-se que os primeiros a pensarem em ruptura com o absolutismo português viessem a se estabelecer em Minas Gerais. ${ }^{25}$ Esta assertiva da revista nos parece importante para se atentar, pois não nos esqueçamos da biblioteca do cônego e conjurado Luís Vieira da Silva, onde poderiam ser encontrados os principais clássicos da ilustração. ${ }^{26}$

Poderíamos nos estender ainda mais sobre esta documentação. Mas o que nos ocupamos doravante é a reação da Igreja em relação a estas ideias. Ainda em fins do século XIX, o ultramontano José Maria Correia de Sá e Benevides ${ }^{27}$ em seu livro Elementos da Philosofia do Direito Privado e "em quem as mais puras e respeitáveis crenças religiosas cada vez mais se aprofundão pelo estudo e reflexão,28 nos daria algumas pistas de como seria essa reação católica. Em seu prefácio, Benevides diz:

\footnotetext{
${ }^{23}$ Neder, Gizlene (2007). "O bibliotecário-mor e o iluminismo jurídico coimbrense". In Neder, Gizlene; Cerqueira Filho, Gisálio. Op. cit, p. 52. Ver também Darnton, Robert (1996). O Iluminismo como negócio: história da publicação da Enciclopédia (1775-1800), São Paulo: Cia. das Letras.

${ }^{24}$ A tese de doutoramento de Maria Luíza Penna nos traz também alguns referenciais importantes para a percepção das ideias modernas em Minas Gerais já desde os primórdios do século XIX. A este respeito a autora destaca alguns episódios políticos do Primeiro Reinado (1822-1831) e do período regencial (18311840), entre os quais estaria a extinção da Vila de Caeté e a criação da Vila de Itabira. Momentos como estes revelam a grande circulação e o uso - que é bem sintomático - das ideias da ilustração na defesa e na importância de um pacto social contra os excessos que por ventura poderia vir a exercer despotismo. Ver: Penna, Maria Luíza (2006). Luiz Camillo. Perfil de um intelectual, Belo Horizonte: Editora UFMG, p. 81 e 107.

${ }^{25}$ BSTF. Revista da Faculdade Livre de Direito de Minas Gerais. Rio de Janeiro: Typ. Leuzinger, 1895, p. 141-2.

${ }^{26}$ Frieiro, Eduardo (1981). O diabo na livraria do cônego. 2 ed, São Paulo: Ed. Itatiaia: Ed. da Universidade de São Paulo, p. 13-62.

${ }^{27}$ Quem foi José Maria Correia de Sá e Benevides? Nascido em Campos dos Goytacazes (1833) e falecido em São Paulo (1901). Foi presidente da província de Minas Gerais (1869-1870) e do Rio de Janeiro (1870). Cursou direito em São Paulo, onde também foi lente de Direito Natural, Público e das Gentes e Direito Romano; foi também um dos 40 membros fundadores do Instituto dos Advogados daquela cidade. Diz Antonio Carlos Villaça que Benevides foi uma figura muito curiosa. Era católico, ultramontano, antiliberal, portanto, um tomista do Império, porém, leitor de Krause, o que Ihe conferia um perfil eclético. Villaça, Antonio Carlos (2006). O pensamento católico no Brasil, Rio de Janeiro: Civilização Brasileira, p. 77.

${ }^{28}$ BN. Setor de periódicos. Resenha Jurídica. Ouro Preto, abril, 1884, p. 237-9.
} 
Resolvi escrever esta obra, convicto da necessidade de compendiar os princípios da sciencia do Direito Natural em sua harmonia com o Christianismo.

A maior parte dos Compendius, que se tem grande circulação, achase imbuída dos princípios racionalistas absolutos, de theorias revolucionárias e protestantes. Não contesto completamente. Mérito dos escritores, pois reconheço que, a par do seu racionalismo absoluto e liberalismo revolucionário, há muitas doutrinas verdadeiras. Seu estudo é, porém, perigoso á mocidade, porque nessas obras há o erro e a verdade com engenhosa mistura. (...)

A philosophia social da maior parte dos Compêndios mais em voga é dominada pelo espírito do século XVIII, revolucionário e antichristão, ou pelo espírito do século XIX, que, depois de doutrinário ou eclético e de racionalista harmônico, manifesta tendência para a philosofia positivista ou materialista.

É indispensável, pois, que se vulgarizem as doutrinas de Taparelli, de Rosmini, de Bensa e de outros notáveis philosophos catholicos que luminosamente têm escripto sobre a philosophia do direito, reagindo contra as doutrinas no século $X V I I I .{ }^{29}$

Como pode-se perceber por esta fala de Benevides, o racionalismo, o liberalismo e o protestantismo são aspectos doutrinários em linha de colisão com o pensamento católico ultramontano. Tendo em vista esta situação, a Igreja procuraria restabelecer sua influência nos meios políticos e intelectuais a partir da década de 1910. Em sua Carta Pastoral de 1916, o recém-nomeado arcebispo de Recife e Olinda e futuro arcebispo do Rio de Janeiro a partir de 1921, Dom Sebastião Leme, externava a todos o posicionamento da Igreja em relação a esta situação. Neste documento, Dom Leme chamava a atenção para

[...] a fragilidade da Igreja institucional, as deficiências das práticas religiosas populares, a falta de padres, o estado precário da educação religiosa, a ausência de intelectuais católicos, a limitada influência política da Igreja e sua depauperada situação financeira. ${ }^{30}$

Os resultados dessa empreitada logo começariam a aparecer. De acordo com Riolando Azzi, na década de 1920, os sinais de repactuação entre a Igreja, a política e os intelectuais já seriam notados. É nesta época que são fundadas associações de leigos voltadas para atuar, entre outros, no campo social, como é o caso da Ação Católica, onde encontraremos o católico converso Jackson de Figueiredo e, depois de sua morte, outro

\footnotetext{
${ }^{29}$ BN. Setor de periódicos. Resenha Jurídica. Ouro Preto, abril, 1884, p. 237-9. Grifo nosso.

${ }^{30}$ Mainwaring, Scott (2004). Igreja Católica e política no Brasil (1916-1985), São Paulo: Brasiliense, p. 41
} 
converso Alceu Amoroso Lima ou ainda D. Hélder Câmara. Ligadas à Ação Católica, duas outras instituições também eram destaque naquele tempo, isto é, a União dos Moços Católicos e o Centro D. Vital. ${ }^{31}$ Este fora criado em 1922 por Jackson de Figueiredo e, juntamente com a revista A Ordem, criada em 1921, fez emergir, segundo Mainwaring, uma das mais influentes gerações de líderes católicos leigos que se tem conhecimento na América Latina, a qual viria a ter um importante papel na cultura política desse período. Até 1928, no entanto, afirma Mainwaring, este movimento não havia logrado grande êxito em Minas Gerais, mas por intermédio de petições em defesa dos interesses católicos, pouco a pouco, o pensamento racionalista e positivista, herdado das décadas anteriores, foi cedendo espaço à neocristandade. "Sob todos esses aspectos", diz, "a Igreja mineira antecipou mudanças que iriam ocorrer em nível nacional, principalmente sobre a liderança de Dom Sebastião Leme e do Centro Dom Vital". ${ }^{32}$

No caso brasileiro, entendia-se que a religião deveria ser um dos elementos que contribuiria para a formação dos elementos constitutivos da nacionalidade brasileira em que o liberalismo, a democracia e o socialismo eram vistos com restrições por parte dos clérigos reformadores. Assim sendo, Azzi destaca que os bispos buscavam direcionar sua pastoral para a recuperação do prestígio que a Igreja vira abalado nos primeiros anos da República e neste caso a família e a escola eram os principais focos sobre os quais ela deveria agir. Em relação à primeira, entende-se que um dos seus principais alvos era a indissolubilidade do casamento e, em relação à segunda, pairava uma concepção de que o ensino deveria ser católico, afinal, se a maioria do povo brasileiro era católica, a maior parte dos estudantes também o era. ${ }^{33}$

Em Minas Gerais, estas relações nos parecem muito evidentes. Em 1921, o clero se posicionava amplamente a favor da candidatura de Arthur Bernardes para a presidência da República. Em uma carta publicada no Estado de Minas o bispo D. Cyrillo de Paula Freitas ${ }^{34}$ disse que não via outro candidato mais digno para ocupar a presidência da República.

\footnotetext{
${ }^{31}$ Azzi, R. (1992). Op. cit, p. 189-91.

${ }^{32}$ Mainwaring, S. (2004). Op. cit, p. 46. Participavam também do Centro Dom Vital: Hamilton Nogueira, Gustavo Corção, Plínio Correia de Oliveira, Sobral Pinto, Perilo Gomes, Allindo Vieira e Jônatas Serrano. Na década de 1940, numa postura mais progressista, pode-se identificar uma corrente liderada por Alceu Amoroso Lima e Dom Hélder Câmara. O conhecimento da obra do inglês Gilbert K. Chesterton - referência católico-tomista para os intelectuais brasileiros nesta época - ficaria expresso em relação a Gustavo Corção, que chegou a redigir uma biografia dele. Ver: Corção, Gustavo (1946). Três alqueires e uma vaca, Rio de Janeiro: Livraria Agir Editora.

${ }^{33}$ Azzi, R. (1992). Op. cit, p. 189-91.

${ }^{34}$ Nesse tempo, D. Cyrillo de Paula Freitas estaria na Diocese de Corumbá no Mato Grosso, assumida em 1917. Ver: Miceli, S. (1988). Op. cit.
} 
Quem como eu, tem seguido a açção administrativa e política do doutor Arthur Bernardes, não esquiva-se de abraçar enthusiasticamente essa sympática candidatura. Como cidadão e como catholico, presto o meu franco, leal e decidido apoio ao seu nome impoluto. ${ }^{35}$

D. Cyrillo faz questão de ressaltar que Arthur Bernardes era um católico declarado e sincero e assim sendo seria para ele incompreensível como um eleitor católico e sincero não votaria em Bernardes, não se podendo dizer o mesmo de seu antagonista, portanto, seu oponente nas eleições daquele ano - Nilo Peçanha ${ }^{36}$ - que no breve período em que ocupou a presidência da República nada deixou que o recomendasse à estima e a gratidão pública. ${ }^{37}$

Dois meses antes, Arthur Bernardes havia dado uma entrevista para $A$ União onde também colocou suas impressões em relação à Igreja Católica. De início, Bernardes destaca que fora educado nesta religião, mais especificamente pelos padres lazaristas do Colégio do Caraça. Seu apreço pelo catolicismo é muito grande diz, pois, afinal é a religião da maioria dos brasileiros e estes a ela muito deviam, se observada sua ação desde os primórdios de nossa história. Alguns destes traços, destaca Bernardes, seria a sua contribuição para a formação moral do povo brasileiro, a educação da infância, assim como a assistência à pobreza, à orfandade e aos indigentes, estes, diz, um dos mais belos traços de sua ação social. Perguntado em relação ao divórcio diz que, enquanto deputado federal, votara contra o projeto que o instituía, com base nas razões largamente debatidas naquela casa. Em relação ao ensino religioso ou, como frisa a entrevista, a liberdade de se ensinar a religião nas escolas públicas, diz que sua prática não ofende 0 preceito constitucional que estabelece a ampla liberdade de cultos no país.

Disse ainda que "ninguém melhor do que Rui Barbosa, notabilíssimo exegeta da nossa Constituição, firmou a doutrina que deve prevalecer na solução deste problema". Assim como nos Estados Unidos, diz que a liberdade religiosa no Brasil só trouxe benefícios à Igreja. Levando-se em consideração que com o fim do padroado esta pode atuar de forma mais livre na difusão de sua doutrina, certamente Bernardes estava com a razão, uma vez que, no Império, o padroado e o beneplácito limitariam esta ação.

Interessante notar como Bernardes se baseia no princípio constitucional e reforça sua postura como republicano. Para ele o ensino leigo não deveria ser confundido com

\footnotetext{
${ }^{35}$ SMBMMM. O Dia, 02 de setembro de 1921, p. 1, col. 6.

${ }^{36}$ Assim como Afonso Pena, Nilo (Procópio) Peçanha também foi um bucheiro e maçom Grão Mestre do Grande Oriente do Brasil. Almeida Filho, J. C. de (2005). Op. cit, p. 56.

${ }^{37}$ SMBMMM. O Dia, 02 de setembro de 1921, p. 1, col. 6.
} 
uma obrigação dos brasileiros à irreligião ou a incredulidade. Destaca ainda que a Igreja e seus bispos vinham dando excelente colaboração para os governos na escola oficial.

Já em relação à questão social, Bernardes fora perguntado se, entre os dois extremos em que ela se achava naquela conjuntura - isto é, a solução socialistaanarquista e a solução cristã - qual ele defenderia? "Oh, não há a menor dúvida: a christã" diz o presidenciável, que, em seguida, defende a manutenção das boas relações do Estado brasileiro com a Igreja que, na medida em que a lei o permita, deveriam ser mais intensas em seu provável governo. Diz ainda que não é nem nunca se filiou à maçonaria $^{38}$ e em relação ao movimento católico no Brasil diz que

[...] é com muita sympatia que noto o augmento progressivo do espírito religioso do nosso povo, cujos guias, no episcopado, no clero secular e nas congregações, dão o exemplo de virtudes e são vultos brilhantes na cultura intelectual. ${ }^{39}$

Vejamos então a resposta dada por Bernardes quando lhe fora colocado o interesse dos católicos na colocação do crucifixo nas escolas públicas de Minas.

Realmente, o meu governo não impediu esse movimento, que se iniciara no quatriênio anterior. Nem há motivo para contrariar a maioria catholica, nossa homenagem. ${ }^{40}$

Bernardes diz que uma vez à frente do governo da República, usará para com a Igreja a mesma justiça que seus antecessores mineiros, destacando a harmonia que deve existir entre o liberalismo de nossa constituição e as convicções religiosas de nossos políticos.

Como nos mostra a entrevista, as boas relações entre Estado e Igreja não eram uma novidade. Ainda no governo de Epitácio Pessoa, o arcebispo de Mariana, D. Silvério Gomes Pimenta, enviou uma circular a seus vigários cujo assunto seria o recenseamento a ser realizado em toda a República em comemoração ao centenário da Independência, em 1922. Para tanto, o arcebispo fala da importância deste trabalho e pede aos párocos para que prestassem todo o apoio moral contribuindo para o serviço dos recenseadores. ${ }^{41}$

\footnotetext{
${ }^{38}$ Embora negue ser maçom Arthur (da Silva) Bernardes tem seu nome citado como bucheiro e maçom. Almeida Filho, J. C. de (2005). Op. cit, p. 51 e 53.

39 SMBMMM. O Dia, 07 de julho de 1921, p. 1, col. 1 e 2.

40 SMBMMM. O Dia, 07 de julho de 1921, p. 1, col. 1 e 2.

41 SMBMMM. O Dia, 20 de julho de 1920, p. 1, col. 2. O Vigário Geral da Diocese de Caratinga, Mons. Aristides Rocha, também recomendou em circular ao seu clero que auxiliasse no bom andamento dos
} 
Qual o interesse da Igreja em colaborar com o governo em um recenseamento? O mesmo D. Silvério se veria chamado a um apoio declarado aos candidatos do Partido Republicano Mineiro (PRM) nas eleições federais que se realizariam no ano de 1921. Dizia o deputado Rocha Lagoa Filho, que inúmeros boatos estavam sendo espalhados pelo estado dizendo que o bispo apoiava outro candidato o que, na sua concepção, seria extremamente prejudicial ao desempenho dos candidatos do PRM, devendo D. Silvério buscar uma solução para que estes não fossem vistos como inimigos do catolicismo. ${ }^{42}$

Nas eleições de 1930, o jornal A Luz, da diocese de Aterrado, acusava o candidato da oligarquia paulista, Julio Prestes ${ }^{43}$, de não estar de acordo com os sentimentos da família brasileira. A sua possível eleição era vista pelo jornal como uma perspectiva de calamidade, posto que a bancada do Partido Republicano Paulista (PRP), com a anuência do então presidenciável, apresentara um projeto de "divórcio a vínculo" no Congresso Nacional. Caso este não fosse aprovado ainda no governo Washington Luís, faria parte da plataforma eleitoral de Júlio Prestes, diz o informativo. Embora dizendo não saber qual a postura do candidato Getúlio Vargas sobre o assunto, o mesmo atesta a confiança que mantinha em outra liderança política brasileira que então apoiava a candidatura da Aliança Liberal, isto é, o governador mineiro Antonio Carlos Ribeiro de Andrada. ${ }^{44}$

Sergio Miceli destaca que o Norte/Nordeste, São Paulo e Minas Gerais foram as três regiões do Brasil em que a Igreja buscou mais atuar na primeira República, aumentando consideravelmente o número de suas dioceses. A seguir, vejamos aquelas que foram criadas nas terras mineiras.

\section{Quadro 1}

Dioceses criadas em Minas Gerais (1890-1930)

\begin{tabular}{|c|c|}
\hline Diocese & Ano de criação \\
\hline
\end{tabular}

trabalhos do recenseamento tomando, tal como o fizera D. Silvério, de um espírito patriótico, para que ajudassem nesta missão.

${ }_{42}$ SMBMMM. O Dia, 5 de fevereiro de 1921, p. 1, col. 1 e 2. Na campanha civilista detectamos uma prédisposição da Igreja em apoiar o candidato Rui Barbosa em detrimento do militar Marechal Hermes da Fonseca. Na visão da Igreja, Hermes era maçom e dizia-se que seu governo seguiria as diretrizes da maçonaria. Rui Barbosa, no entanto, havia entrado quando jovem e ainda estudante de direito em São Paulo em uma loja maçônica (Bucha), mas havia negado o culto ao bode preto há mais de 40 anos. Era o candidato ideal. Não se deveria dar atenção aos boatos de que Rui era o anticatólico, espalhado por partidários de Nilo Peçanha e Hermes da Fonseca. Na verdade, defendia-se que Rui era o único em que se poderia recorrer para combater a maçonaria. Ver: SMBMMM. O Pharol, 21 de dezembro de 1909, p. 1, col. 1 e 2 .

${ }^{43}$ Foi bucheiro e indicado candidato à presidência pelo também bucheiro e maçom Washington Luís Pereira de Souza. Almeida Filho, J. C. de (2005). Op. cit, p. 56-57.

${ }^{44}$ AHCJF. Diário Mercantil, 16 de setembro de 1929, p. 1, col. 1 e 2. 


\begin{tabular}{|c|c|}
\hline Pouso Alegre & 1901 \\
\hline Campanha & 1907 \\
\hline Uberaba & 1907 \\
\hline Montes Claros & 1910 \\
\hline Araçuaí & 1913 \\
\hline Caratinga & 1915 \\
\hline Guaxupé & 1916 \\
\hline Aterrado & 1918 \\
\hline Belo Horizonte & 1921 \\
\hline Juiz de Fora & 1924 \\
\hline
\end{tabular}

Fonte: MICELLI, Sergio (1988). Op. cit., p. 63

Neste contexto, as fontes destacam que o campo jurídico também seria afetado. Vejamos que o apelo a posicionamentos intelectuais marcadamente centrados no cientificismo entre esses homens das letras jurídicas teve vozes que the seriam dissonantes. Como o saber jurídico passou a oferecer uma resposta científica em assuntos que até então se encontravam, sobretudo, nas mãos da instituição eclesiástica, operou-se assim, um estado de concorrência entre estes dois campos e formou-se o que Pierre Bourdieu chamou de um campo de lutas pela

[...] manipulação simbólica da condução da vida privada e orientação da visão de mundo, e todos colocam em prática na sua visão de mundo, definições concorrentes, antagônicas, da saúde, do tratamento da cura dos corpos e das almas. ${ }^{45}$

Essa crítica ao cientificismo no campo jurídico ficaria expressa já na década de 1930, com a publicação da revista Surto, voltada para os estudantes de direito da Universidade de Minas Gerais (UMG). Em suas páginas, nos foi possível encontrar uma defesa muito explícita da filosofia tomista e muito instigante para o nosso propósito de estudo, uma vez que, em função do processo de cientificização por que havia passado no rastro século XIX, seriam os intelectuais do campo jurídico um dos alvos do processo de recristianização encampado pela Igreja naquelas primeiras décadas do século XX. Neste caso, como destacaria Artur Versiani Veloso - um de seus articulistas -, a filosofia naqueles anos pós-Primeira Guerra Mundial estaria descaracterizada pelo cientificismo e

\footnotetext{
${ }^{45}$ Bourdieu, Pierre (2004). "A dissolução do religioso”. In Coisas ditas, São Paulo: Brasiliense, p.119-25.
} 
racionalismo provocando o que se poderia chamar de uma "atomização" da sociedade. Mas, em uma rota de colisão com este tipo de pensamento estaria, em seu entender, o tomismo, difundido naquele tempo nos escritos de intelectuais que entrariam no Brasil pelas mãos da Ação Católica, como Jacques Maritain, Emmanuel Mounier e Gilbert K. Chesterton. $^{46}$

Ademais, o grande líder da intelectualidade católica a partir da década de 1930 Alceu Amoroso Lima - se converteria em uma presença constante sobre os intelectuais do campo jurídico - não somente de Minas Gerais, mas de todo o Brasil. Neste caso, suas conferências, além de divulgar a literatura católica introduzida no país pela Ação Católica, divulgava também a filosofia de São Tomás de Aquino. Isso seria sintomático se tomarmos por referência um artigo de Edgard Godói da Mata Machado publicado em 1955 pela Revista da Faculdade Livre de Direito de Minas Gerais relativo à ética profissional do advogado, segundo São Tomás de Aquino. ${ }^{47}$ Como o próprio autor explica, seus alunos da faculdade de direito o tomavam sempre com questionamentos relativos à "generalizada mercantilização das atividades humanas", que diziam assistir naquele tempo. Estes acadêmicos, diz Mata Machado, mantinham, sobretudo, vínculo com a Juventude Universitária Católica (JUC), que, por sua vez, também era tributária da Ação Católica brasileira. Como essa seria uma temática recorrente, Mata Machado procurou responder-Ihes tomando por referência a Secunda Secundae da Summa Theologiae (questão 71), onde São Tomás estuda as injustiças cometidas pelo advogado. Um elemento também importante neste documento é a utilização por Mata Machado de um texto original e de uma tradução em língua francesa feita pelo dominicano Ceslas Spicq.

O que nos chama a atenção nesse artigo? Em primeiro lugar, é São Tomás fazer uma discussão em relação à atuação profissional do advogado ainda no século XIII, quando difundia seus escritos. Assim também, é a própria inserção de São Tomás no âmbito acadêmico e, mais precisamente, no âmbito do direito. Notemos como Mata Machado revela-se um bom conhecedor da filosofia tomista e a própria solicitação de acadêmicos vinculados à JUC nos leva a entender que várias outras leituras de pensadores católicos circulavam no mundo acadêmico naquela época. Enfim, percebe-se que se lê, se estuda, se discute, se escreve sobre o tomismo entre os intelectuais do campo jurídico.

\footnotetext{
${ }^{46}$ BN. Setor de Periódicos. Surto. Belo Horizonte, Ano 1, no 3, fevereiro-março 1934, p. 64-8.

${ }^{47}$ Ver: Mata Machado, Edgar Godoi da (1955). "A ética profissional do advogado segundo Santo Tomás de Aquino". In Revista da Faculdade de Direito de Minas Gerais. Belo Horizonte, p. 91-102.
} 
Pela análise que fizemos em relação às demais publicações jurídicas, a circulação de ideias tomistas (ou neotomistas) e autores católicos entre os intelectuais do campo jurídico, sobretudo referente à área jurídico-penal, tornam-se recorrentes já a partir dos anos 1920. Justamente neste contexto, os juristas brasileiros estariam voltados para as discussões referentes à reforma do Código Penal Brasileiro. Neste caso, quando o mesmo veio a entrar em vigor, em 1940, pode-se dizer que as ideias defendidas pelo positivismo em relação ao crime, isto é, a de que o mesmo seria definido por fatores biológicos, não veio a ser vitoriosa. Uma das razões que defendemos para que não se tenha assumido essa filosofia jurídico-penal nesta legislação explica-se a partir da força que as ideias religiosas tomistas passaram a assumir em meio aos intelectuais do campo jurídico.

Dos vários textos que analisamos a partir, sobretudo, da Revista Forense, nos foi possível ver como se desconstrói uma crença que até então seria evidente em relação aos postulados científicos voltados para o entendimento do crime e da criminalidade. $\mathrm{E}$ esse foi um papel muito bem desempenhado pelo jurista Nelson Hungria (1891-1969) ${ }^{48}$ figura recorrente no periodismo jurídico brasileiro dos anos 1930 e 1940. Para Nelson Hungria, nas academias de direito formadas no Brasil ainda no século XIX

\footnotetext{
48 "Nelson Hungria Hoffbauer nasceu a 16 de maio de 1891, no Município de Além Paraíba, estado de Minas Gerais. Era filho de Alberto Teixeira de Carvalho Hungria e de D. Anna Paula Domingues Hungria. Fez o curso primário no Colégio Cassão, em Belo Horizonte, o secundário no mesmo estabelecimento, no Colégio Azevedo, em Sabará, e no Ginásio Nogueira da Gama, em Jacareí, Estado de São Paulo. Realizou o curso de direito da Faculdade Livre de Direito do Rio de Janeiro. Iniciou a vida pública como Promotor Público em Pomba, estado de Minas Gerais; foi Redator de Debates na Câmara dos Deputados de Minas Gerais e Delegado de Polícia no antigo Distrito Federal. Ingressou na Magistratura como Juiz da 8o Pretoria Criminal do antigo Distrito Federal, nomeado por decreto de 12 de novembro de 1924. Serviu posteriormente como Juiz de Órfãos e da Vara dos Feitos da Fazenda Pública. Ascendendo ao cargo de Desembargador, em 1944, exerceu as funções de Corregedor. Nomeado Ministro do Supremo Tribunal Federal, por decreto de 29 de maio de 1951, pelo Presidente Getúlio Vargas, para a vaga decorrente da aposentadoria do Ministro Annibal Freire da Fonseca, tomou posse em 4 de junho do mesmo ano. (...) Mediante concurso, obteve a livre docência da cadeira de Direito Penal da Faculdade Nacional de Direito. Participou da elaboração do Código Penal, do Código de Processo Penal, da Lei das Contravenções Penais e da Lei de Economia Popular. Escreveu inúmeras obras sobre direito penal, destacando-se: Fraude Penal e Legítima Defesa Putativa - teses destinadas à conquista da cátedra universitária - Estudos sobre a Parte Especial do Código Penal de 1890; Crimes contra a Economia Popular; Questões Jurídico-Penais; Novas Questões Jurídico-Penais; Comentários ao Código Penal (8 volumes) e ainda Cultura, Religião e Direito; O Sermão da Montanha e A Obrigação Absoluta no Direito Cambiário. Participou ativamente de congressos nacionais e internacionais, entre os últimos, o $2^{0}$ Congresso Latino-Americano (Santiago, Chile, 1947); 3ํㅡ Congresso Latino-Americano de Criminologia (1949) e Jornadas Penales (Buenos Aires, Argentina, 1960). Foi agraciado com a Medalha Rui Barbosa, Medalha do Rio Branco, Medalha do Sesquicentenário do Superior Tribunal Militar, Medalha Teixeira de Freitas, Comenda do Mérito do Ministério Público e o prêmio Teixeira de Freitas, outorgado em 1958, pelo Instituto dos Advogados Brasileiros, pela obra Comentários ao Código Penal. (...) Faleceu em 26 de março de 1969, na cidade do Rio de Janeiro, sendo homenageado pelo Supremo Tribunal Federal em sessão da mesma data, falando pela Corte o Ministro Luiz Gallotti; pela Procuradoria-Geral da República, o Dr. Décio Miranda e, pela Ordem dos Advogados do Brasil, Seção do Distrito Federal, o Dr. Antonio Carlos Osório". Texto extraído de: http://www.stf.jus.br/portal/ministro/verMinistro.asp?periodo=stf\&id=133; acesso em 18 de janeiro de 2010.
} 
[...] o estudante era doutrinado, de preferência na desabrida crítica ao direito penal constituído e na inconciliável polêmica das "escolas" sobre o que devia ser, mais ou menos utopicamente, o novo direito penal. Nem era de exigir-se diversa orientação de ensino para formar bacharéis destinados a embasbacar juizes leigos. Aos advogados criminais nada mais era preciso que cultivar $o$ gênio patético ou o estilo condoreiro e imprimir a marca de ciência exata as lucubrações do nihilismo penal, cuja bandeira vermelha fora desfraldada por César Lombroso. ${ }^{49}$

Nelson Hungria será assim uma dessas lideranças jurídicas que mais se oporiam a uma tentativa de filiação do Código Penal de 1940 à escola positivista. Em 1942, numa discussão sobre as novas escolas penais em voga naqueles tempos, às quais dizia ter se filiado o "moribundo positivismo", Hungria foi criticado por sua postura em não "tomar conhecimento dos novos dados recolhidos pelas ciências médicas" pelo médico Leonídio Ribeiro, a quem, em resposta, Hungria dizia ser filiado "no estudo desse ramo seco da ciência, que se chama antropologia criminal. ${ }^{50}$ Nessa linha de raciocínio, Hungria não deixaria de apresentar também um estudo crítico relativo às ideias e intelectuais que defendiam, por meios estatísticos, que os negros seriam os mais propensos ao crime fundamentando-se nos estudos de Franz Boas, Artur Ramos e Gilberto Freyre, autor do célebre Casa-Grande \& Senzala, mas que também se notabilizava pelo seu apreço à filosofia católico-tomista. ${ }^{51}$

Em uma de suas discussões relacionadas à responsabilidade penal, notamos que Bergson - para o qual a ciência não era a maior fonte de conhecimento e entendia que a intuição seria muito mais importante que esta, e era um dos filósofos pelos quais os intelectuais do campo católico teriam grande apreço naqueles anos - viria a ser um de seus referenciais.

Fixemos, por exemplo, pela sua preponderância, o tema da responsabilidade penal, baseada, de jure constituto, na responsabilidade moral, que, por sua vez, assenta no postulado da vontade livre. É pela porta deste tema que se entra no âmbito da ciência penal. Houve um tempo em que o libertinismo da vontade humana foi colocado num mostruário de museu, entre a vértebra de

\footnotetext{
${ }^{49}$ BTJRJ. Hungria, Nelson (1943). "A evolução do Direito Penal brasileiro". In Revista Forense. Vol. XCV, Rio de Janeiro, julho, p. 6.

50 BSTF. Hungria, Nelson (1942). "O Código Penal e as novas teorias criminológicas". In Revista Forense, Vol. XCl, Rio de Janeiro, agosto, p. 26-7.

51 BTJRJ. Hungria, Nelson (1951). "A criminalidade dos homens de cor no Brasil". In Revista Forense, Vol. CXXXIV, Rio de Janeiro, março, p. 7-9.
} 
um megatério e uma múmia egípcia; mas foi lá buscá-lo, de novo, a teoria do conhecimento, a confirmar, uma vez mais, a doutrina dos retrocessos de Vico. A ciência, a serviço da filosofia materialista, apregoara o causalismo universal, a que não podia forrar-se a psique humana, e negara, a pés juntos, a liberdade volitiva do homo erectus et sapiens. A demonstração, porém, firmava-se numa simples e sumária dedução generalizadora, e pode Bergson, um dos maiores cérebros da era contemporânea, fazendo a intuição suprir o limitado alcance da inteligência, formular a sua interrogação: se o movimento molecular pode criar sensação com um nada de consciência, por que a consciência não pode criar, por sua vez, movimento, seja com um nada de energia cinética e potencial, seja utilizando essa energia a seu modo $?^{52}$

O que fica evidente nessa defesa de Hungria é que a vontade não poderia ser descartada - tal como seria pelos defensores da escola positivista - como elemento a ser pensado para entender o que leva uma pessoa a um ato criminoso. Em outras palavras, as certezas que o pensamento científico dizia produzir, seriam por ele questionadas. Desse modo, se levarmos em consideração as próprias descobertas da ciência naquela primeira metade do século $X X$, essas certezas estariam sendo desconstruídas tendo em vista descoberta da Teoria da Relatividade por Albert Einstein. Mais uma vez, Hungria fez referência a este momento para justificar os cuidados que o jurista deveria ter em relação a um cientificismo que mal havia conseguido colocar a "luz na imensa noite da ignorância humana" e já colocava "Einstein no altar em que adorava Newton como deus único e verdadeiro!'. 53

Segundo Hungria, na exposição dos motivos feita pelo Ministro da Justiça Francisco Campos, estaria também expressa essa defesa da capacidade volitiva do homem, isto é, a liberdade da vontade. Diz Francisco Campos que

sem o postulado da responsabilidade moral, o direito penal deixaria de ser uma disciplina de caráter ético para tornar-se um mero instrumento de utilitarismo social ou de prepotência do Estado. Rejeitando o pressuposto da vontade livre, o código penal seria uma congérie de ilogismos. ${ }^{54}$

Como dissemos também, essa postura antimaterialista que a filosofia impunha servia muito bem como um elemento legitimador para aqueles que incrementavam a

\footnotetext{
52 BSTF. Hungria, Nelson (1942). "Introdução a Ciência Penal". In Revista Forense, Vol. XCll, Rio de Janeiro, outubro, p. 8.

${ }_{53}$ BSTF. Hungria, Nelson (1942). "Introdução a Ciência Penal". In Revista Forense. Vol. XCII, Rio de Janeiro, outubro, p. 12.

${ }^{54}$ BSTF. Hungria, Nelson (1942). "Introdução a Ciência Penal". In Revista Forense. Vol. XCII, Rio de Janeiro, outubro, p. 11.
} 
inserção do tomismo entre os intelectuais do campo jurídico. O que nos chama a atenção é que a defesa da vontade como aspecto a ser pensado para entender a criminalidade acaba por desaguar no livre-arbítrio como elemento a ser reconhecido pelos juristas na ciência do direito penal. ${ }^{55}$ Seria esta postura defendida por todos os agentes do campo jurídico? Certamente não! Mas é preciso considerar-se a influência de Nelson Hungria entre estes, sua capacidade de produção intelectual e sua circulação no meio jurídico. Estes artigos até aqui citados foram, em sua maior parte, fruto de conferências realizadas na Ordem dos Advogados do Brasil, em escolas de direito, em congressos jurídicos, em tribunais estaduais ou federais ou entrevistas em jornais de grande circulação nacional, como $O$ Globo do Rio de Janeiro ou A Noite de São Paulo, entre, evidentemente, vários outros.

Em 1941, ao voltar do $2^{\circ}$ Congresso Latino-americano de Criminologia, realizado no Chile, Hungria destacou que os critérios da escola positivista ainda prevaleciam entre a maioria dos penalistas latino-americanos e que os técnico-juristas, os neoclássicos e os unitaristas eram poucos. ${ }^{56}$ Muito embora houvesse diversidade de ideias no congresso, informou que os trabalhos caminharam muito bem, sendo o então recente Código Penal do Brasil alvo de elogios por juristas como Jimenez de Asúa, professor em La Plata, Sebastian Soler e Molinari, professor em Buenos Aires. Como não poderia deixar de ser, Hungria disse:

O leader dos positivistas foi o congressista Euzébio Gómez, um dos autores do projeto do novo Código Penal argentino, que, por sinal, não logrou aprovação, estando em elaboração outro projeto, pelo conhecido professor José Peco. O ilustre e valoroso delegado argentino deu-me a impressão de estar vivendo ainda na época em que Lombroso e Ferri cuidavam ter encontrado a verdade definitiva na ciência criminológica. Como todo bom positivista, Gómez, não quis tomar conhecimento da evolução científica que sucedeu ao advento do famoso projeto Ferri na Itália e sua brilhante inteligência continua ao serviço de uma corrente de idéias já inteiramente ultrapassada. ${ }^{57}$

\footnotetext{
55 BSTF. Hungria, Nelson (1942). "Introdução a Ciência Penal". In Revista Forense. Vol. XCll, Rio de Janeiro, outubro, p. 12.

${ }^{56}$ BSTF. Hungria, Nelson (1941). "Entrevista: O Brasil no Congresso de Criminologia do Chile". In Revista Forense. Vol. LXXXV, Rio de Janeiro, p. 820.

${ }^{57}$ BSTF. Hungria, Nelson (1941). "Entrevista: O Brasil no Congresso de Criminologia do Chile". In Revista Forense. Vol. LXXXV, Rio de Janeiro, p. 820. Percebe-se pela Revista Forense as trocas entre Brasil e Argentina no campo do direito e, em específico do direito penal. Sobre este, escreveria a revista em relação a Sebastião Soler: "Os argentinos, menos tracionalistas do que os brasileiros, são por isso muito mais positivos no direito penal. Lá o positivismo tem honras de doutrina oficial, pela maioria que o aplaude e pelos grandes nomes que o defendem. Tiveram Ingenieros, Oswaldo Loudet, Euzebio Gomez, Alfredo Molinario, Jose Peco e vários outros, sendo Sebastião Soler uma exceção". Ver: Revista Forense, Rio de Janeiro, Agosto, 1940, p. 367. Indicamos também a crônica escrita por Roberto Lira sobre os criminalistas argentinos. Ver: Lira, Roberto (1930). "Os criminalistas argentinos". In Revista Forense. Rio de Janeiro,
} 
Por fim, o que gostaríamos de mostrar a partir deste texto é que as discussões em relação às ideias políticas e jurídico-penais podem ser entendidas em meio a esse processo de restauração católica do século XX. A leitura das fontes aqui apresentadas nos deixa transparecer que, em meio a esses campos, haveria um esforço de recristianização. O liberalismo e o positivismo seriam, com o tempo, questionados e abririam espaço para que a filosofia católico-tomista viesse a substituí-los. Como procuramos mostrar, a literatura jurídica seria levada ao diálogo com escritores cujas ideias seriam recorrentes entre os intelectuais do campo católico. Assim também, instituições como as escolas de direito, os tribunais e demais associações jurídicas seriam visitadas por um laicato católico que então estaria se responsabilizando por essa reaproximação.

Uma vez que as ideias e as ideologias liberais e positivistas, em voga no século $\mathrm{XIX}$, acabariam por atuar em áreas que até aquele momento seriam uma responsabilidade da Igreja, tal qual a educação, a assistência social e, por conseguinte, a família, seria necessário atuar sobre aqueles que de certo modo estariam atuando no interior do campo de poder e tomariam as decisões políticas compatíveis com as diretrizes relacionadas a essas ideias e ideologias. Neste caso, o setor jurídico seria um referencial importante para a atuação da restauração católica no século $X X$ e para a construção da chamada neocristande.

Neste caso, Minas Gerais, como nos mostra Scott Mainwaring, viria a ser o principal alvo desse processo de restauração católica. Se levarmos em consideração as tensões no campo das ideias e os embates que pudemos lançar neste texto, além é claro, da própria organização católica nestas paragens talvez possamos entender o porquê desse olhar tão certeiro do clero sobre as minas. ${ }^{58}$

\section{Fontes}

1. Biblioteca Municipal Murilo Mendes/Setor de Memória - Juiz de Fora (MG) - Periódicos:

1.1. O Dia

1.2. O Pharol

2. Arquivo Histórico da Cidade de Juiz de Fora - Periódico:

Outubro, p. 227-228; e um apanhado geral da produção das letras jurídicas na Argentina. Ver: Carneiro, Levi (1940). "O livro jurídico argentino". In Revista Forense. Vol. LXXXIV, Rio de Janeiro, outubro, p. 502-5.

${ }^{58}$ Mainwaring, S. (2004). Op. cit, p. 46. 


\subsection{Diário Mercantil}

3. Biblioteca Nacional:

3.1. Setor de Periódicos

3.1.1. Resenha Jurídica

3.1.2. Surto

3.2. Setor de Obras Raras

3.2.1. Imprensa Acadêmica

3.2.2. Academia

4. Bibliotecas do Supremo Tribunal Federal (DF) e do Tribunal de Justiça do Estado do Rio de Janeiro (RJ):

4.1. Revista da Faculdade Livre de Direito de Minas Gerais

4.2. Revista Forense

\section{Bibliografia}

Almeida Filho, José Carlos de (2005). O ensino jurídico, a elite dos bacharéis e a maçonaria no século XIX. Dissertação (Mestrado em Direito, Estado e Cidadania) Universidade Gama Filho, Rio de Janeiro.

Azzi, Riolando (1992). A Igreja e o menor na historia social brasileira, São Paulo: Cehila/Edições Paulinas.

Vozes.

(2008). História da Igreja no Brasil. Terceira Época - 1930-1964. Petrópolis:

Barata, Alexandre Mansur (1999). Luzes e sombras: a ação da maçonaria brasileira, Campinas: Editora da Unicamp.

Beal, Tarcísio (1977). "As raízes do regalismo brasileiro". In Revista de Cultura Vozes, Petrópolis: Vozes, vol. LXXI, no 3 .

Bourdieu, Pierre (2004). "A dissolução do religioso". In Coisas ditas, São Paulo: Brasiliense, p. 119-125.

Corção, Gustavo (1946). Três alqueires e uma vaca, Rio de Janeiro: Livraria Agir Editora.

Darnton, Robert (1996). O lluminismo como negócio: história da publicação da Enciclopédia (1775-1800), São Paulo: Cia. das Letras.

Freyre, Gilberto (1948). Ingleses no Brasil, Rio de Janeiro: Livraria José Olympio Editora. 
Frieiro, Eduardo (1981). O diabo na livraria do cônego. 2 ed, São Paulo: Ed. Itatiaia: Ed. da Universidade de São Paulo.

Gammon, Samuel Rhea (2008). The evangelical invasion of Brasil, Bibliolife, 2008.

Maia, Almir de Souza.(2000). "O descobrimento tardio: as raízes, o nascimento e os atuais desafios da universidade brasileira". In Impulso: Revista de Ciências Sociais e Humanas da Universidade Metodista de Piracicaba, Piracicaba. v. 12, $\mathrm{n} \cong 27$.

Mainwaring, Scott (2004). Igreja Católica e política no Brasil (1916-1985), São Paulo: Brasiliense.

Mendonça, Antônio Gouvêa; Velasques Filho, Prócoro (2002). Introdução ao protestantismo no Brasil. 2 ed, São Paulo: Edições Loyola/Programa Ecumênico de Pósgraduação em Ciências da Religião.

Miceli, Sergio (1988). A elite eclesiástica brasileira, Rio de Janeiro: Bertrand Brasil.

Nabuco, Joaquim (1873). A invasão ultramontana. Discurso pronunciado no Grande Oriente do Brasil, dia 20 de maio de 1873, Rio de Janeiro: Typographia FrancoAmericana.

(1873). O partido ultramontano: suas invasões, seus órgãos e seu futuro. Artigos publicados, Rio de Janeiro: Typografia da Reforma.

Neder, Gizlene \& Cerqueira Filho, Gisálio (2007). Ideias jurídicas e autoridade na família, Rio de Janeiro: Revan.

Penna, Maria Luíza (2006). Luiz Camillo. Perfil de um intelectual, Belo Horizonte: Editora UFMG.

Santos, Cândido (2007). O jansenismo em Portugal, Porto: Faculdade de Letras da Universidade do Porto.

Ubillús, P. José Antônio. Passo a passo com São Vicente. Oficina no 3, Dezembro/2003, p. 4. (mimeografado). Disponível também em http://www.aicinternational.org/pdf/pas34port.pdf acesso em 30 de julho de 2009.

Vieira, David Gueiros (s/d). O protestantismo, a maçonaria e a questão religiosa no Brasil. 2 ed, Brasília: Editora da UnB.

Villaça, Antonio Carlos (2006). O pensamento católico no Brasil, Rio de Janeiro: Civilização Brasileira. 